THUR:SDAY, JUNE 8, I893.

\section{THE ROYAL SOCIETY ELECTION.}

HAD it not been for the unnecessary and indiscreet communication to the newspapers of a letter not intended for the public eye, the difference of opinion which made itself manifest at Burlington House last Thursday might have been settled in a purely domestic manner. As it was, it gave rise to comments which, in most cases, were as absurd as they were painful to the persons concerned. But the mischief is done and it would be affectation to deny that a question of considerable moment has been raised and one which will very probably provoke in the future a good deal of discussion and consideration. Clearly, therefore, it has to be faced, and I willingly accede to the wish of the Editor of NATURE to state why I think the policy of the dissentients should not be accepted by the general body of the Fellows of the Royal Society.

I say policy, bec ıuse I think it must be obvious to every one that the matters involved go a good deal deeper than the personal interests which were at stake. And here I would say at once that looking at the names of the dissentients, it is impossible to suppose that those who proposed to reject the recommendations of the Council were animated by anything but perfect good faith, and a real desire to act in the best interests of the Royal Society. Though I entirely disagree with them, I say this with the more conviction as they were nearly all my own personal friends. The harshest thing I should be disposed to say of their action is that while it had the uncompromising honesty, it also hail the unreasonable narrowness of a somewhat provincial point of view.

Every one will I suppose admit that in most administrative matters the English people are above all things practical and are little influenced by considerations of either logical order or of mere symmetry. The Royal Society appears to je a notable case in point. It is unlike any analogous institution, as far as I know, in the world. It is by no means a mere Academy of Science. Looked at historically and from the point of view of actual facts, it is seen to be an association of persons of "light and leading" who wish to promote the interests of science especialy in so far as they are a matter of national concern. I use deliberately the rather hackneyed words "light and leading" as descriptive of the qualifications of its members. They fall in fact into the two categories; on the one hand they consist of the most competent experts in different branches of science and on the other of prominent men in the political and social world who are sympathetic to science and desirous of promoting its progress as an indispensable phase of our life and intellectual development as a nation.

Now it seems to me that the real importance of the proceedings of last Thursday was the attack which was virtually made and with some vigour on this position. The dissentients in their printed statement completely ignored its existence. I can only make the excuse for them which Dr. Johnson made when a lady asked him to account for a very palpable blunder in his dictionary. "Ignorance, ma'an, sheer ignorance." It seems there- fore worth while to show that in including in the fifteen selected candidates a man of public distinction who was not a professional man of science the Council acted in accordance with well-established tradition and precedent which has not hitherto been seriously challenged.

In other countries where Government is constituted on more bureaucratic lines than it is in this, men of science associate themselves in bodies to which non-scientific members of the community have no access. Such bodies can address the state, and are doubtless listened to with the respect due to expert authority. But the reason is mainly because science under such conditions falls into line with general bureaucratic arrangements. In England the expert as such is more usually listened to with hesitation. It is my belief that if the Royal Society were simply constituted of professional scientific men, its influence in the country would be vastly diminished. Englishmen are distrustful of experts whom they think, and I must admit too often with justice, to be cramped in their general outlook and wanting in knowledge of the world. Furthermore Englishmen are curiously shy of what they don't comprehend. A purely professional Royal Society would be apt to be treated with a kind of ironical respect but otherwise severely left alone as a thing "no fellow can understand."

Now it may be asked reasonably, would this be a desirable state of things? I think it may be shown with little difficulty that in the interests of scientific progress in this country it would not. Consider for a moment the kind of work which the Royal Society does. In the first place, and I suppose the dissentients would say that this is its only proper function, it signalises and marks out those workers in science as to whose integrity and competence it has satisfied itself. But this might be done by a small and exclusive club, and though such a body would be distinguished, it would never enjoy the distinction which attaches to the Royal Society. That distinction rests on the fact that it possesses a quasiofficial position in the State. It is therefore on the one hand able to approach the Government of the day with a recognised status and authority to speak; on the other hand it is the supreme scientific tribunal from which the Government can count on obtaining a perfectly impartial judgment on questions of importance to the community. Here it may be replied that a strictly-restricted scientific Academy could equally fulfil those functions. In any other country, I have already admitted that it may be so. But here again national peculiarities must be reckoned with. In this country most important Government business is in all essential features settled in a semiofficial way. Preliminary pour-parlers ascertain what applications would be acceptable and what will be conceded to them. The official letters which are ultimately exchanged only put on record what has been previously negotiated. It is here that the presence of what I may call a sympathetic lay element in the Society is so in. valuable. A statesman or public man by becoming a fellow has solemnly pledged himself to co-operate with his colleagues. A minister therefore who is an F.R.S. cannot refuse, in common courtesy, to lend his ear to representations to which as a politician he might be very willing to be deaf.

No doubt there was a time when this lay element tended 
to swamp the Society and to destroy its scientific prestige. But the Royal Society is not a thing of yesterday; and accumulated experience has shown the way to the present modus vivendi which appears to me to have given the maximum advantage to the scientific world over which the Society presides without the remotest possibility of injurious interference.

It may be well to consider in what this lay element consists. In the first place we have the Sovereign who was the Founder and is always the Patron and may in the future as in the past take an active part in the Society's proceedings. Next there are the Princes of the Blood any one of whom may at any time be summarily proposed for election. The original statutes provided that any one of the rank of Baron or higher should be qualified for election. That privilege was however abolished in the present century, no doubt as opening the door to the lay element too widely. But the privilege was retained for the Privy Council, a body which in its constitution is analogous to the Royal Society inasmuch as access to it can only be obtained outside the Royal Family by conspicuous ability independently of mere rank or birth. And it may be noticed that the analogy is drawn even closer by the recent admission to the Privy Council of a scientific element. Each body has in fact in relation to the State its own field of activity and functions. But they are often not very dissimilar. A committee of the one body may advise the Government on the constitution of a new university; a committee of the other may equally advise it on the methods of obviating explosions in mines. We may have a Privy Councillor discussing at Burlington House Marine Signals or Colour Vision, while a late president of the Society may be occupied at Whitehall in determining whether the Eternity of Future Punishment is a binding article of the English faith.

But besides members of the Privy Council it has been the custom time out of mind to elect into the Society as ordinary fellows men of conspicuous public position and merit, with the proviso, however, that they should in their careers have shown themselves sympathetic to science. Such elections, however, differ in toto from the honorary and merely complimentary degrees conferred by the Universities. Such men are brought into the Society, first, in recognition of their services to science, secondly, to confirm them in their interest in it, lastly, that their cooperation may be secured in the performance of the Society's public work. The Society in order to effectively accomplish that for which it exists must be in touch with other fields of national life; it requires and turns to good account its connections with society, with the legislature, with the bench, with Government administration. By including in their number a body of distinguished public men, the Fellows of the Royal Society are able to enormously enlarge their influence and to display themselves as reasonable if hard-headed men of the world, perfectly able to play their part in affairs which concern them on equal terms with those who make the conduct of affairs their only business and by no means as mere recluses in a laboratory. Can any more effective mode be imagined for removing from scientific men that suspicion of impracticable pedantry with which men of science are too often regarded by the uninformed?

In the face of these considerations which $I$ had thought were part of the well-known traditions of the Society I confess that the hubbub of last Thursday somewhat amazed me. It was fought over a man who is preeminently of the kind that the Royal Society has been always willing to coopt. A man of singular modesty but vast learning, a scientific historian with the keenest sympathy for science, a member of the legislature who by his own unaided merit has acquired for himself a conspicuous position amongst the statesmen of the day. If the principle of the admission of laymen is admitted at all, who could be more suitable?

The simple fact is that there was nothing anomalous in the matter. Any one who has taken part in the selection of candidates by the Council will know that there is a regular category for lay candidates presented on their public form. The Council has to make up its list with due regard to the claims of every branch of science. But I think I cannot be far wrong if I assert that in most recent years it has been the practice to select on an average one layman annually. There are at least a dozen in the existing list and the obituary notices abound with them. It is perhaps invidious to mention names but I may single out of those living Sir Henry Barkly, Sir William Jervois, Sir John Kirk, Sir George Nares, Sir Bernard Samuelson, Sir George Verdon, Sir Charles Warren. Any of these men would probably disclaim any pretension to be considered a professional man of science. But each and all of them has rendered great services to it, and the recognition of this by the scientific world is the best way to get other distinguished public men to imitate their example.

If I have discussed the question at some length it is because it seems to me to be one of vital importance to the welfare of the Society. But the dissentients took a further step which if it were to become a precedent would be absolutely disastrous. They not merely proposed that one of the candidates selected by the Council should be rejected but without consulting him proposed that another whom the Council had not recommended should be elected. It is true that in their first circular the dissentients stated that the statutes of the Society left no other course open to them. This however is an entire mistake and I am afraid is rather characteristic of the want of due consideration which characterised the whole proceeding.

It appears to me, putting other considerations aside, unlikely that in so delicate a matter any five fellows can arrive at a sounder conclusion than the twenty-one who form the Council. Any fellow who has been a member of that body must have been struck with the frankness and impartiality with which the merits of the respective candidates are weighed and discussed. And so large a proportion of the Council is changed every year that it would be practically impossible for it ever to come under the control of any one party in the Society, if there be such a thing. It appears to me therefore that all presumption is in favour of the judgment of the Council and I think that experience has shown that in the vast majority of cases it has been exercised wisely.

It will be generally agreed that in no branch of science can those who follow it arrive at a correct estimate of the merits of those who work in other branches without the responsible evidence of men with the necessary technica!

NO. [ 232 , VOL. 48 ] 
knowledge. Now this testimony the Council both receives and has the opportunity of carefully sifting. Having arrived at a judgment accordingly, it appears to me that that judgment should not be lightly upset unless in the almost inconceivable case of its being utterly outrageous.

Councils have erred in the past, and I suppose the Council of the Royal Society cannot claim infallibility. It might be necessary therefore for the general body of fellows to correct its action. The election of a fellow is an irretrievable step. To oppose it is a grave but it may be a justifiable procedure. But to over-ride the Council's discretion in not selecting a particular candidate is a much graver one. Non-selection is not an irretrievable injury and if in any one year it may seem to inflict some injustice on a particular candidate its redress when justified by merit is not difficult of attainment on a subsequent occasion. But if a precedent were established for taking the matter out of the nands of the Council, peace and good feeling in the ranks of the Society would soon vanish. In time every election would be the occasion of a conflict and no one who valued his self-respect would care to serve on the Council. Nor is there any reason to think that any substantial gain would accrue. A man may be rushed to the front by a wave of temporary and emotional popularity. Such a man, if the fellows acquired the habit of meddling with the Council's prerogative of selection, might be forced prematurely upon the Society. In the long run it is not improbable that those who resorted to such a practice might live to regret their precipitancy.

W. T. Thiselton-Dyer.

\section{VERTEBRATES OF ARGYLL AND THE INNER HEBRIDES.}

A Vertebrate Fauna of Argyll and the Inner Hebrides. By J. A. Harvie-Brown and T. E. Buckley. (Edinburgh : David Douglas, 1892.)

DERTINACITY in an endeavour to carry out the results of a fixed idea has almost always been regarded as a virtue, even when the principle involved has seemed to be hopelessly mistaken, and thus the adherents of the Stuart and other lost causes still find sympathisers at the present day; but when none can doubt the value of the idea, the pertinacity with which it is supported, provided that obstinacy is left out, becomes a virtue that in these practical days is not easily exaggerated. Such pertinacity is conspicuously exhibited by the authors of the book before us, Mr. Harvie-Brown and his worthy coadjutor, Mr. Buckley. This "Vertebrate Fauna of Argyll and the Inner Hebrides" is the fifth of a series of volumes, the inception of which is vastly creditable to its founder, the gentleman first named, and to all concerned in its production-even to the printer's devil and the binder's apprentice. Some of its predecesisors have before received notice in these columns ; ${ }^{1}$ but it has perhaps never been made clear to the readers of NATURE that this series of books is placing the zoology of the northern Kingdom on a footing which has not been attained, nor is likely to be attained in the southern part of the island, even though there exist particular English

1 "A Vertebrate Fituna of Sutherland, Caithness, and West Cromarty," NATURE, Xxxi. p. 2:2; "A Vertebrate Fauna of the Outer Hebrides," NATURE, xl. p. IOI.

NO. 1232 , VOL. 48$]$ works-but this solely so far as ornithology is concerned-of merit superior to any one of the Scottish productions, the volume on Orkney; which is of remarkable excellence, being perhaps an exception. It is not difficult, however, to account to a considerable extent for this superiority: the proportion of persons with a taste for natural history to the general population being presumably the same in both parts of Great Britain, the enormously greater population of England would naturally furnish a larger number than Scotland is able to show. This is not said in derogation of the northern kingdom. It has always been rich in botanists; and, among zoologists, the single name of William Macgillivray is enough to cover it with renown. However much his merits, and especially his originality, may have been obscured or underrated in his life-time, he has already been recognised by those who have taken the trouble to inform themselves, and especially by American writers, as the most original British worker in regard to the vertebrate division of animals, since the incomparable pair-Willughby and Ray. But of Macgillivray this is not the place to speak particularly. On some other occasion we hope we may say more of him, a man whose work by some unhappy fate failed to impress his contemporaries, and whose posthumous volume was oppressed by princely patronage-well-meant but illadvised. He had little or no experience of "Argyll and the Inner Hebrides," and really does not now come into our story. ${ }^{1}$

As a matter of fact it is hard to say who among old naturalists does deserve especial mention in connexion with the Faunal District of which this volume treats. Mr. Harvie-Brown, with the caution characteristic of his nationality, abstains from putting forth the claim of any predecessor; though, as brave men lived before Agamemnon, this district may have had a zoological historian before the laird of Dunipace and Quarter. The late Mr. Henry Davenport Graham-an honest observer if there ever was one-whose pleasant contributions to the ornithology of Iona and Mull, illustrated by some of his humorous and very clever sketches, were published in 1890 as a "relief volume " of the present series, belongs of course to the existing epoch, for he died in 1872 ; and moreover his observations were confined to but a small portion-the islands just named-of the district. Thus as regards its ancient history from the zoological point of view, we have an absolute void, since the Statistical Accounts (both Old and New) of the county of Argyll and the Isles give as little information to the purpose as does the often-quoted but seldom-read description of Dean Monro, which was only published in 1774,225 years after it was written. ${ }^{2}$

To come to closer quarters, we are inclined, though we must say so with diffidence, to question Mr. HarvieBrown's delimitation of his "Faunal District." In principle he is undoubtedly right, though somehow or other the result does not seem to work out well. His principle was laid down in the first volume of the seriesthat on Sutherland, Caithness, and Western Cromartyand is the marking out of a district by physical features rather than by political boundaries. No naturalist ought

${ }^{1}$ His portrait is given by our authors in their volume on "The Outer Hebrides."

"A reprint of this very rare work was published at Glasgow in $188_{4}$ (by Thomas D. Morrison). 